\title{
Why didn't they ask Evans?
}

\author{
Chris S. M. Turney \\ School of Biological, Earth and Environmental Sciences (BEES), University of New South Wales \\ (UNSW), Sydney, NSW 2052, Australia (c.turney@unsw.edu.au)
}

\section{Received March 2017}

ABSTRACT. Arguably the best known scientific Antarctic venture was the British Antarctic Expedition of 1911-1913 led by Captain Robert Falcon Scott. Whilst the so-called race to the geographic South Pole with Roald Amundsen's Norwegian Antarctic expedition excited international interest, the tragic death of Scott and his returning Polar Party was a striking reminder of the hazards of operating in the south. Recent work has highlighted the possible role expedition second-in-command Lieutenant Edward 'Teddy' Evans played in the deaths of Scott and his men. Here I report newly discovered documents which, when placed in a wider context, raise significant questions over Evans' behaviour during the expedition. The evidence focuses on the shortage of food at key depots, the apparently deliberate obfuscation of when Evans fell down with scurvy and the failure to pass on orders given by Scott. It is concluded that Evans actions on and off the ice can at best be described as ineffectual, at worst deliberate sabotage. Why Evans was not questioned more about these events on his return to England remains unknown.

\section{Introduction}

Few ventures in the Antarctic have excited as much public interest as the British Antarctic Expedition (BAE) of 1911-1913. Privately funded, the extensive scientific programme 'off the map' aimed to be the first to reach the geographic South Pole. Sadly, the expedition ended in tragedy, with the deaths of Captain Robert Falcon Scott and his four sledging companions on their return to base, beaten in their pursuit by Roald Amundsen's Norwegian team (R. F. Scott, 1913a). The Royal Geographical Society (RGS) had supported the British venture and, as President, Lord Curzon soon became the public face of the BAE with his call for donations to commemorate the dead men, publication of scientific results and support for their families (The Times, 15 February 1913, London: 7).

Of the five men in Scott's party, Petty Officer (P.O.) Edgar Evans was the first to die, apparently from the effects of concussion at the base of the Beardmore Glacier (Fig. 1). Later, suffering from frostbite and exhaustion, and recognising his ever-slowing pace was threatening the others, Captain Lawrence 'Titus' Oates bravely walked out into a blizzard with the words, 'I am just going outside and may be some time.' In plummeting temperatures with limited food and fuel, Scott, Dr Edward Wilson and Henry 'Birdie' Bowers were pinned down by a nine-day blizzard and died sometime around 29 March 1912 (R. F. Scott, 1913a), 150 days out from base and just $18 \mathrm{~km}$ from the aptly named One Ton Depot. One year later, their bodies were discovered with $16 \mathrm{~kg}$ of fossil-rich rocks collected as part of the returning scientific programme.

There has been considerable speculation surrounding the events that led to the death of Scott and his men. Possible contributing factors include extreme weather (Cherry-Garrard, 1922; Simpson, 1923a; Solomon, 2001; Solomon \& Stearns, 1999), contaminated food (BomannLarsen, 2006) and poor decision making by Scott (Huntford, 2009). Recent reports have identified contradictions in the testimony of Lieutenant Edward 'Teddy' Evans (hereafter, 'Evans'), who was second-in-command to
Scott when the BAE headed south (Turney, 2012, 2014). Evans led the last party to see Scott and his men alive and his subsequent actions raise serious questions over the role - however inadvertent - he may have played in the deaths of the five men.

\section{First concerns}

On 14 April 1913, Kathleen Scott returned to London from New Zealand, two months after the public announcement of her husband's death. She immediately contacted Lord Curzon and arranged for a meeting two days later to discuss the content of her late husband's diary and correspondence (Curzon, 1913a; K. Scott, 1913). Concern had already been raised in some quarters over what might have happened on the ice. On 15 March 1913, Admiral Lewis Beaumont, Fellow of the RGS, had written to Kathleen Scott:

It is good that you should have time to read quietly, and think over all that has come to you from him - it will enable you to decide what to do and be prepared for what the future may have in store... I cannot but think that more has happened than has been mentioned and that the diaries and journals that were sealed, contained things which had been done or said which it was not for those into whose hands the diaries had first fallen to reveal - I may be wrong - I hope most sincerely that I am, but I cannot put away the sense of fear which comes from knowing so much of the expedition and its members... I dread the gradual coming out of the painful revelations when the whole of the Expedition's people have dispersed to their homes... God grant that there may be nothing that will give you pain or add to your burden! (Beaumont, 1913a).

At their meeting, Curzon made notes of what appears to have been a wide-ranging discussion with Kathleen Scott (Curzon, 1913c). In these notes, the RGS President wrote that, 'Oates no doubt took opium \& then killed himself', suggesting that the British army officer had 


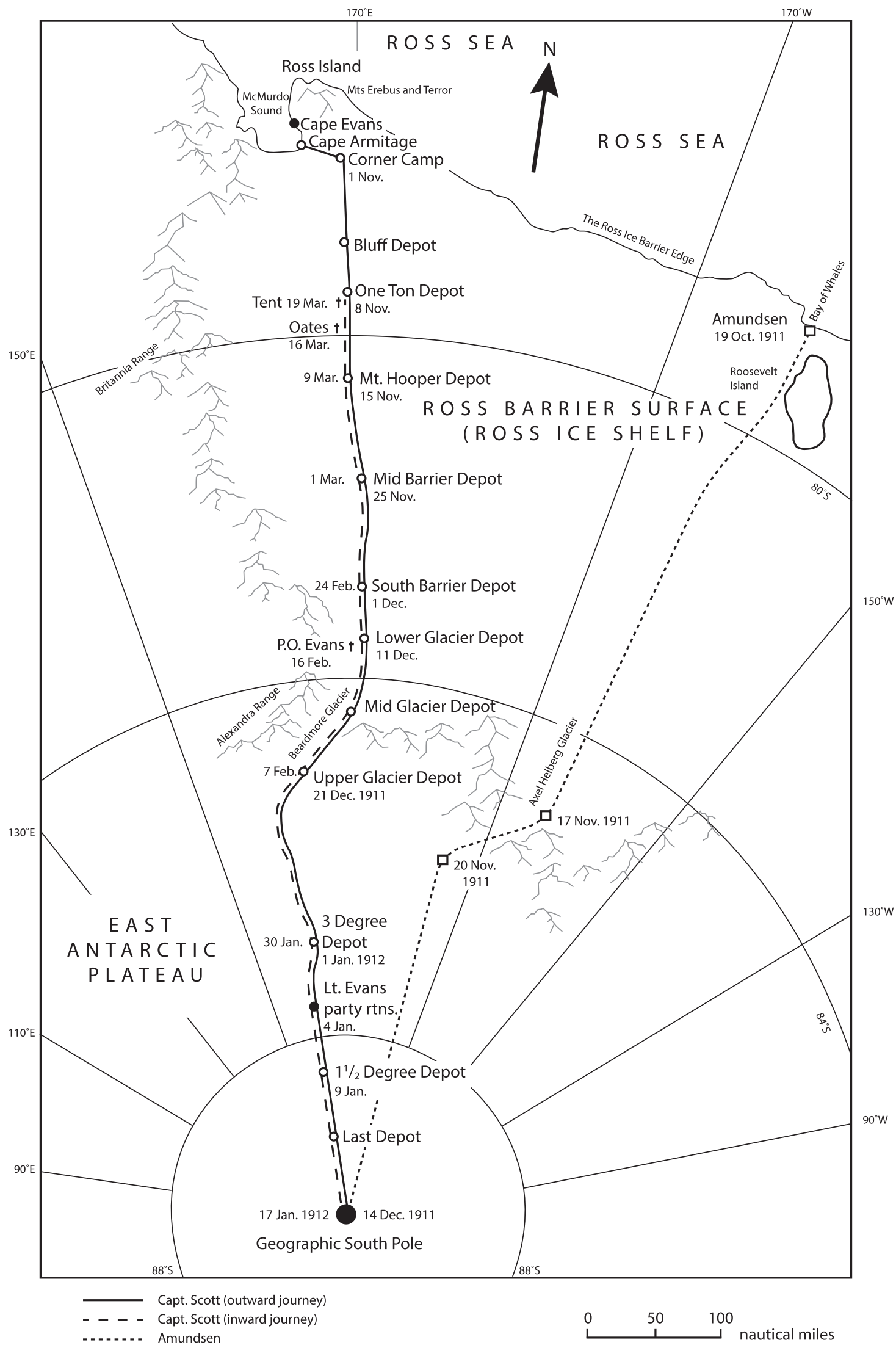

Fig. 1. Route out (solid line) to geographic South Pole and return journey (long dashed lines) taken by Captain Scott and team with key dates. Also shown are depots (open circles) with the point of return of Lieutenant Evans' Last Supporting Party (solid circle, 4 January) and the deaths of P.O. Evans and Captain Oates (crosses). Route taken by Amundsen's Norwegian Antarctic expedition from the Bay of Whales is also shown (short dashed lines). Modified from Crane (2006). 
understandably needed drugs to walk out into the storm that took his life. But the big surprise was Scott's 'words in his Diary on exhaustion of food \& fuel in depots on his return. He spoke in reference of "lack of thoughtfulness \& even of generosity". It appears Lieut Evans - down with scurvy - and the two men with him must on return journey have entered \& consumed more than their share.' This revelation implied that the returning party led by the expedition's second-in-command had taken more than their allocation of supplies.

In response, Curzon appears to have initiated an inquiry within the RGS. Most of the Fellows were supportive (Darwin, 1913; Goldie, 1913) but Beaumont was circumspect. In a letter marked 'Confidential', the retired admiral expressed concerns:

...[T]he important point, to my mind, being the necessity of deciding what attitude the Society should take with regard to your questions (a) \& (b) that is:the exhaustion of the supplies of food \& fuel - and the conduct of the relief parties. I am not in favour of the informal meeting becoming a Committee of Enquiry because for the Society to be on sure ground it would have to probe very deep and would have probably to disapprove of what was done in many particulars - it would be different if good could come of the enquiry, but I fear nothing but controversy would come of it (Beaumont, 1913b).

A point he repeated to Kathleen Scott (Beaumont, 1913c).

Curzon seems to have initially persisted in his efforts to hold an enquiry, possibly because of the intensifying media attention led by The Strand Magazine who were making strident efforts to have full access to Scott's diaries (Curzon, 1913b). Beaumont continued to argue against:

I beg of you to meet first to talk the matter over, before calling any of the members of the Expedition before you. I am quite sure that to do this would be equivalent to holding an enquiry which personally I am very anxious to avoid. The rumour would be certain to go the rounds of the papers that the Geographical Society had held an enquiry - they would probably say 'a secret meeting' (Beaumont, 1913d).

Around the time of these discussions, Curzon met Edward Wilson's widow, Oriana (O. Wilson, 1913), which provided a crucial part of the expedition's story:

Mrs Wilson told me later there was a passage in her husband's diary which spoke of the 'inexplicable' shortage of fuel \& pemmican on the return journey, relating to depots which had not been touched by Meares and which could only refer to an unauthorised subtraction by one or other of the returning parties. This passage however she proposes to show to no one and to keep secret (Curzon, 1913c).

Cecil Meares was leader of the returning dog sledge team across the Ross Ice Shelf and was known to have removed extra supplies from the Mount Hooper Depot (Fig. 1). The dogs had outperformed expectations with the result that Meares had travelled the entire ice shelf on the outward journey; the extra two weeks required further supplies and
Meares had left a letter informing others of his actions. Curzon's notes imply someone other than Meares had taken supplies from another depot and Kathleen Scott had implicated Evans. At this critical time news reached London that on Evans' return to the UK, his wife Hilda had become critically ill (The Sun, 18 April 1913, Sydney: 8) and days later passed away after suffering from peritonitis (The Register, 21 April 1913, Adelaide: 8). There appears to have been widespread thought that Evans had suffered enough (Atkinson, 1913). Shortly after, the enquiry seems to have been closed with Beaumont writing to Curzon on 24 April 1913 thanking him for the 'unanimous decision of your committee' (Beaumont, 1913e). By July 1913, Evans had been removed from the official leadership of the expedition.

The above suggests Curzon was considering an enquiry to focus on two issues. First, had Evans, who was suffering from scurvy, taken extra supplies on his return journey to save his own life, but potentially to the fatal disadvantage of Scott and his team? And second, what orders had been given, and perhaps ignored, for the relief of the Polar Party (Curzon, 1913c)?

\section{First problems}

London-born Evans (later 1st Baron Montevans) first visited the Antarctic as second officer on the Morning, a relief vessel sent south to help break out Scott's National Antarctic Expedition (1901-1904) vessel, the RRS Discovery, which was trapped by sea ice in McMurdo Sound. Although keen to lead his own expedition, the former President of the RGS Sir Clements Markham convinced Evans to be Scott's second-in-command on the BAE.

Preparations for the BAE began almost as soon as the Discovery expedition returned to Britain. To ensure success, Scott proposed using motorised sledges for hauling supplies and equipment across the Ross Ice Shelf to relieve the workload on the horses, dogs and men. For this, Scott approached friend and colleague from the Discovery expedition Reginald Skelton, a naval engineering officer, in 1907 (Skelton, 1907). With 'an 8-10 HP petrol motor' and two-air cooled cylinders, the sledge was designed to pull a substantial load at five kilometres an hour. By March 1910 the sledge was successfully negotiating slopes and dragging sledges in Norway, steered by an individual pulling on a rope (Skelton, 1910b). Scott hoped that the motorised sledges would be as effective in the south for transporting supplies across the Ross Ice Shelf. He later recorded in his diary:

A small measure of success [for the expedition] will be enough to show their possibilities, their ability to revolutionise Polar transport (R. F. Scott, 1913a).

Evans, however, appears to have had serious misgivings about his position relative to Skelton, who held the higher military rank of commander (Skelton, 1911). Skelton could not understand the problem and challenged Evans: 
The reason I am told is that 'on account of my seniority, it would be extremely difficult for you when Capt Scott is absent'... I should be obliged if you would tell me when it seemed to you that I was not suitable to the expedition and when you placed your objections, in view of the fact that you knew I had been connected with the motor sledge work for the past 2 or 3 years... (Skelton, 1910a; Turney, 2012).

Skelton offered to take a civilian role but Evans flatly refused (Skelton, 1911). Scott was forced to remove Skelton from the expedition, with the inevitable loss of technical support for the motorised sledges.

The BAE set out on the Terra Nova from Cardiff in June 1910 and by January 1911 had established its main base at what became known as Cape Evans on Ross Island, $24 \mathrm{~km}$ north of Scott's Discovery base at Hut Point (near Cape Armitage; Fig. 1). To support the large research programme, particularly during the following summer sledging season, talks were given by expedition members. The scientists described the latest research questions and their plans; expedition 'camera artist' Herbert Ponting gave lectures on photography in the field. On 18 August 1911, medic Edward 'Atch' Atkinson presented on 'Scurvy which was very good, producing much discussion and merriment. $\mathrm{He}$ began by telling us the ravages it made in the old days... He then described the symptoms - swelling of gums, tiny red patches on legs, flaccidity, weariness, swellings, nose bleedings etc...' (Back, 1992). One of the youngest men on the team, Apsley Cherry-Garrard, later wrote how Atkinson's lecture and the experience of others on the expedition had shown that fresh seal meat was an 'antidote to scurvy' (Cherry-Garrard, 1922). No one really knew the cause. A reliance on tinned food was known to be bad and increased acidity in the blood hinted at some deficiency (R. F. Scott, 1913a). Although Vitamin $\mathrm{C}$ was discovered in 1912, it would be another 20 years before its importance for the prevention of scurvy was fully realised. Fortunately, fresh seal meat appeared to have an ingredient that kept scurvy at bay. Scientist Frank Debenham remarked in his diary that 'Ponting summed up the lecture as disappointing from his point of view as it seemed to him that if he didn't eat seal-meat he would get scurvy and if he did he would get rheumatism' (Back, 1992). The need to use it so affected Ponting that in his movie of the expedition, The great white silence, he included mention of the need of seal meat to 'guard against that dread disease, "scurvy"' (Ponting, 1924).

On the ice, Scott's concerns over Lt. Evans' abilities intensified, possibly made worse by increasing problems with the motor sledges. On 6 January 1911, Scott remarked in his diary:

The motor sledges are working well, but not very well; the small difficulties will be got over, but I rather fear they will never draw the loads we expect of them (R. F. Scott, 1913a).

With the forced loss of Skelton, Scott had reached out and recruited Bernard Day, motor specialist on Shackleton's Antarctic Nimrod expedition when the Anglo-Irishman had taken the first motor vehicle south. But the improvised engineering experience does not appear to have been sufficient. By 24 October, 'the motors seemed ready to start and we all went out on the floe to give them a "send off". But the inevitable little defects cropped up, and the machines only got as far as the Cape. A change made by Day in the exhaust arrangements had neglected the heating jackets of the carburettors; one float valve was bent and one clutch troublesome' (R. F. Scott, 1913a).

Scott's frustration at his second-in-command was expressed in his private writing:

Evans himself is a queer study. His boyish enthusiasm rallies all along till one sees clearly the childish limitations of its foundation \& appreciate that it is not a rock to be built upon - being desirous to help everyone he is manfully incapable of doing it. There are problems ahead here for I cannot consider him fitted for a superior position though he is physically strong \& fit for a subordinate. The $\ldots \ldots \ldots$ seems incapable of expanding beyond the limits of an astonishingly narrow experience (K. Scott, 1913).

Scott's lack of confidence in Evans was well known amongst the team, with Debenham penning on 14 November 1911:

Teddy Evans, 2nd in command is a very nice jolly fellow with overflowing spirits (out of sight of the Owner [Scott]) but he is not unfortunately the right man in the right place and relations between him and the Owner are rather strained - the fault I think, being 6 of one and half a dozen of the other. He is great fun in company but I don't like being alone with him his confidences are too overwhelming and ill-advised (Back, 1992).

By the eve of his departure for the Pole, Scott's views on Evans appear to have crystallised and he wrote to his expedition manager Joseph Kinsey in New Zealand:

Teddy Evans is a thoroughly well-meaning little man, but proves on close acquaintance to be rather a duffer in anything but his own particular work. All this is strictly 'entre nous', but he is not at all fitted to be 'Second-in-Command', as I was foolish enough to name him. I am going to take some steps concerning this, as it would not do to leave him in charge here [at the Cape Evans base] in case I am late returning (Scott, 1911).

A view Scott apparently shared in writing with numerous people prior to his departure, including Beaumont (Atkinson, 1919). The implication was clear: Scott had no intention of taking Evans to the Pole and meant either to demote him or send him back to New Zealand.

Setting out for the Pole the next day, the motorised sledges were immediately plagued by technical issues and struggled in the extreme weather. Just beyond Corner Camp on 4 November (Fig. 1), Scott remarked:

We found the motor ... Notes from Evans and Day told the tale. The only care had been used for [Seaman William] Lashly's machine, and it would have taken a long time to strip Day's engine so that it could run off 
three cylinders. They had decided to abandon it and push on with the other alone (R. F. Scott, 1913a).

Two days later the remaining machine failed, 'The big end of No. 1 cylinder had cracked, the machine otherwise in good order' (R. F. Scott, 1913a). With sufficient spares and the experienced Skelton, how much further might the motorised sledges have taken supplies? Historian Roland Huntford has suggested 'fifty or hundred miles ... is not insignificant' (Huntford, 2009), a distance that would have made all the difference a few months later. In spite of his opposition to Skelton's participation and the problems that ensued on the ice, Evans was publicly critical of the sledges on his return from Antarctica:

...[A] week after Lashly and I had first set out as the pioneers with those wretched failures, the motor sledges... (Evans, 1921).

Unfortunately, Evans' insistence that Skelton be removed from the expedition almost guaranteed such a result.

As the expedition crossed the Ross Ice Shelf and climbed the Beardmore Glacier onto the Plateau, depots of supplies were laid down for the return journey and the supporting sledging parties were sent back to Cape Evans. Whilst it is inevitable that there would be moments of friction working in such an extreme and isolating environment, there are a surprising number of critical comments singling out Evans in the diaries. Scientist Charles 'Silas' Wright, evidently frustrated, wrote in his diary on 19 December 1911:

Our sledge is slow and can[']t keep up with the Owner's. Teddy, the damn hypocrite, as soon as he sees the Owner's sledge stopped and they watching us come up puts his head down and digs in for all he is worth (Bull \& Wright, 1993).

Cherry-Garrard remarked in his sledging diary on 14 December that the sentiment was shared by many:

Wright wanted to push Teddy Evans down a crevasse. When we dropped the oil cans down we never heard them reach the bottom. It is a pity he didn't (Fiennes, 2003).

As they pushed south, Scott remained silent over who would be in the final sledging team to make the attempt on the Pole. On 20 December, Wright was sent back with one of the returning teams. Wright was furious:

Atch, Cherry, [P.O.] Keohane and I turn back tomorrow night. Scott a fool. Teddy goes on. I have to make course back. Too wild to write more tonight (Bull \& Wright, 1993).

But two-and-a-half degrees north of the South Pole, Scott held a private meeting with Evans (Gran, 1961). The expedition second-in-command was told he would not be continuing on to the Pole but instead would be leading the Last Supporting Party back.

During Evans' return to base he collapsed on the Ross Ice Shelf with scurvy. Losing geological samples to shed weight, Evans' companions Tom Crean and William Lashly dragged him on their sledge. Eventually they could pull no further and Lashly was left with the sick man just south of Corner Camp while Crean heroically walked the remaining $56 \mathrm{~km}$ to Ross Island and returned with help, saving Evans's life. Partially recovered, Evans left on board the Terra Nova when it departed McMurdo Sound for New Zealand on 4 March 1912. Evans was therefore sent home on medical grounds by Atkinson rather than the dismissal envisaged by Scott (Wheeler, 2002).

\section{The changing story of the Last Supporting Party}

Evans was bitterly disappointed not to be included in the Polar Party. On returning home he wrote to former shipmate Captain Paul Irving on 5 July 1912 (Evans, 1912). In this letter, Evans lambasted Scott with a list of complaints including a failure to not recognise his efforts and what he saw as the British leader's appropriation of Bowers from the second-in-command's sledging team. Forced to return one man short, Evans bemoaned:

...Capt. Scott took one of my people, Bowers, to make his hauling easier - thus having 5 men to do what I was expected to accomplish with 3 . When we parted I was as fit as anyone, and scurvy only developed when 300 miles from our base... However his [Scott's] injustice has brought retribution. He has failed in the primary object of his expedition. I return to bring back the party because I started the show and will not be like a rat leaving a sinking ship (Evans, 1912).

The anger at Scott's decision is all too evident. Importantly, however, Evans describes how he fell down with scurvy 300 miles from base, placing him near the Mount Hooper Depot, approximately half way across the Ross Ice Shelf (Fig. 1). Crucially, where Evans fell down with scurvy has been confused over time, helped in no small part by Evans himself. During several media interviews Evans gave after the return of the Terra Nova to New Zealand it was reported that in latitude 80.043, Lieutenant Evans was found to be suffering from scurvy' (The Advertiser, 3 April 1912, Adelaide: 10), consistent with the Irving letter. By the time Evans gave the London public lecture on the BAE's achievements as the surviving expedition leader, the story had changed with him claiming, 'To make things worse, I developed scurvy about January 17, when we had 500 miles to go' (Evans, 1913). This distance was reiterated in The Strand Magazine, where in a published summary of Scott's diary, edited by Evans, it was commented, 'By the time they reached the foot of the [Beardmore] Glacier Lieutenant Evans developed symptoms of the dreaded and exhausting scurvy' (R. F. Scott, 1913b), and also plotted on the map of the route in Scott's last expedition (R. F. Scott, 1913a) (Fig. 1).

The revised location of when and where Evans fell down with scurvy was apparently accepted in The worst journey in the world (Cherry-Garrard, 1922), in spite of Cherry-Garrard's distrust of the second-in-command. With the Antarctic return of a fully recovered Evans on board the Terra Nova in 1913, Cherry-Garrard confided in his diary on 26 January (note that the following text 
in parentheses are Cherry-Garrard's comments on the newspaper report):

I had made up my mind many months ago - before I knew that Evans was left as leader of the Expedition in the case of Scott's death, that I would be as far as I can be, silent as to his disloyalty to Scott, and his failure in the Main Landing Party, especially aggravated as it was by the fact that he will not or cannot pull his sledging literally has been done by others. In a way it seems hard that the return of his Party shall be made the subject of a column in 'the Times'... And so having been got safely to N.Z., Lieut. Evans states that 'he himself was absent from Winter Quarters on surveying work \& depot laying from September 9 until just before leaving on the main sledging journey (lie No 1). During this period he had necessarily to eat sledging rations (lie No 2 \& very wearisome) whereas the other members of the sledging party were in the hut for about 2 months before their departure' (lie No 3 - Scott, Bowers \& Seaman Evans were all away Sept 15 for a fortnight during spring sledging) (CherryGarrard, 1913a).

On 3 March, in reference to Evans, Cherry-Garrard wrote, 'it would be an everlasting shame if the story of this Expedition were told by the one big failure in it.' Atkinson later warned his friend that Evans 'is dangerous and out for trouble. But of that fact I am certain he would not be if he knew the evidence against him and if it could be produced: in case it were needed' (Atkinson, 1919), hinting that there was more to the public narrative than was widely known.

Cherry-Garrard originally intended to write an official account of the expedition and approached William Lashly about the return of Evans' Last Supporting Party (CherryGarrard, 1916). In The worst journey in the world, CherryGarrard describes how he "wrote to Lashly and asked him to meet and tell me all he could remember. He was very willing and added that somewhere or other he had a diary which he had written: perhaps it might be of use? I asked him to send it to me and was sent some dirty thumbed sheets of paper...', implying that he was sent the original. However, Lashly wrote back that he '....could not see any chance of getting away [so] I wrote home for the few notes I took on our southern journey, which I have copied out, and I am forwarding the same on...' (Lashly, 1916). Who sent what to Lashly is unclear, but the important point here is the text delivered to Cherry and reproduced in The worst journey in the world was not a verbatim copy of the original. Inspection of Lashly's sledging diary (Lashly, 1912) indicates the original text is approximately a quarter of the length of that 'reproduced' in The worst journey in the world, and was instead published in full in a little known book called Under Scott's command (Ellis, 1969). In The worst journey in the world, the diary entries end on 22 February; in Under Scott's command they finish on 19 February. The suggestion that the diary entries reported in Under Scott's command are selected sections (Baigent, 2010) is incorrect.
Comparison between Lashly's sledging diary and The worst journey in the world reveals a remarkable embellishment of the entries in the popular account, with key dates pertaining to Evans' scurvy offset by one week (Fig. 2). Consistent with Evans' first interviews and his letter to Irving, the first symptom of scurvy - a stiffness at the back of the knees - was not remarked upon until the men were halfway across the Ross Ice Shelf (30 January 1912), eight days after that described in The worst journey in the world when the men reached the bottom of the Beardmore Glacier (22 January). In his sledging diary, Lashly remarked on 5 February that he was 'beginning to suspect something is wrong with Mr Evans' and five days later the disease is finally mentioned in the diary:

I am sorry to say Mr Evans is suffering from scurvy and very badly ... have come to the conclusion he have got scurvy and bad (Ellis, 1969).

Fortunately, having reached One Ton Depot where special ' $\mathrm{XS}$ ' rations had been left for the returning parties (E. Wilson, 1912b), Lashly now had a greater range of food types than that available further south. As a result, the day after diagnosing Evans with scurvy, Lashly was able to act on the medical advice on the expedition regarding its prevention. In his (original) diary, Lashly wrote on 11 February 1912:

Today no improvement in Mr Evans, but worse. So we have left behind gear. I am giving him [Evans] oatmeal and seal liver and meat out of the pemmican and other changes of food as we have got (Ellis, 1969).

There is no such statement in the version reproduced in The worst journey in the world (Cherry-Garrard, 1922). Unfortunately, Evans' sledging diary no longer exists (J. Evans, personal communication) and no correspondence between him and William Lashly has been found (G. Skinner, personal communication) limiting further investigation. The modified version of the timeline and alignment of events to the public version, however, strongly suggests Evans had considerable input into the text sent to Cherry-Garrard. Years later, Evans himself appears to have forgotten where he fell down with scurvy. In the children's book British polar explorers, he wrote that, 'It is true I developed scurvy when well Northward on the Barrier...' (Evans, 1943).

Evans was the only member on the expedition we know to suffer from scurvy. During newspaper interviews he claimed to have 'subsisted all that time on a diet consisting almost wholly of pemmican' (The Advertiser, 18 May 1912, Adelaide: 20). Whilst pemmican was a key sledging ration it contains virtually no Vitamin C. Unfortunately, supplementing the diet with fresh meat was something Evans chose to ignore. Some years later Debenham remarked:

We did know that seal meat was a preventative, and only one member of our expedition got scurvy in severe form: Teddy Evans... Teddy really was a very naughty boy and wouldn't eat his seal meat. It's not fishy, but it is black, and tastes like very poor steak, 
Scott's Diary and Letters

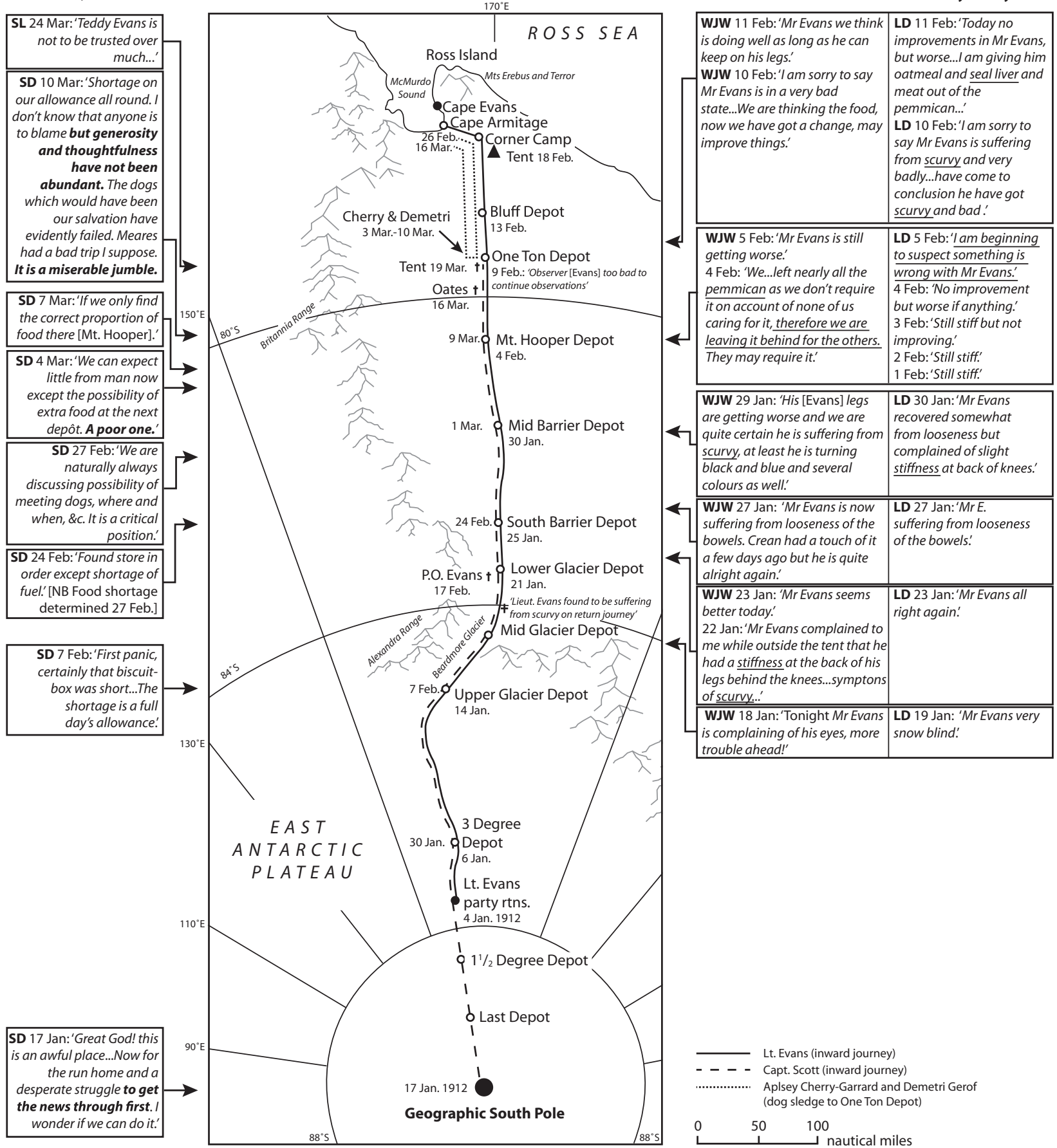

Fig. 2. Route taken by Lieutenant Evans' (solid line) and Captain Scott's (dashed line) parties on their return from the Antarctic Plateau, with Apsley Cherry-Garrard and Demetri Gerof's dog sledge journey to One Ton Depot (short-dashed lines). Summary text with reported location where penned from Scott's diary (SD) (R. F. Scott, 1913a) and letter to Joseph Kinsey (SL) (Scott, 1912b), The worst journey in the world (WJW) (Cherry-Garrard, 1922) and William Lashly's Diary (LD) (Ellis, 1969). Text from Scott's diary not reported in published version are given in bold (R. F. Scott, 1912a, 2008). Key discrepancies in text during the return of Lieutenant Evans' Last Supporting Party identified by comparing the popular account (Cherry-Garrard, 1922) and original diary entries by Lashly (Ellis, 1969) are underlined. Italicised descriptions of Evans' condition on map taken from the published diaries (R. F. Scott, 1913a) and meteorological observations (Simpson, 1923b). 
and the rest of us ate it (Sydney Morning Herald, 27 January 1959, 2).

Evans' refusal to follow medical advice not only jeopardised his own life and the lives of those on his sledging team but as detailed below, others on the expedition. It has remained unclear, however, why such considerable efforts were made to rewrite the timing of events.

\section{Missing food}

The location of the missing supplies recorded by Lord Curzon is not immediately apparent. The returning Polar Party did not reach the Mount Hooper Depot where Meares is known to have taken extra food (and left a note to that effect) until 9 March, 12 days after Edward Wilson's last journal entry. But the published version of Wilson's diary does not refer to any shortage of pemmican (E. Wilson, 1972). To investigate Curzon's claims, high powered microscope analysis of Wilson's pencil entries in his sledging journal at the British Library (E. Wilson, 1912a) does not show any evidence of tampering (W. Frame, personal communication). If Curzon is correct that Wilson noted a shortage of pemmican, then this implies that the comment was made in another document.

Importantly, two sketchbooks were also found with the bodies of Wilson, Bowers and Scott (Bowers, 2012). The perforated pages of these sketchbooks contain numerous detailed sketches and a comprehensive outline of expedition logistics and the science programme - including instructions from geologist Marie Stopes to 'bring home at all costs' any geological samples they discovered with plant remains (E. Wilson, 1912b), evidence crucial to confirm the existence of ancient supercontinent Gondwanaland (Turney, 2012). Inspection of the two books shows six pages have been removed. It is clear from the indentations in the adjoining pages that the missing leaves detailed events on the journey, with one clearly dated as 'Jan 5. 12.' with the latitude given as ' $87^{\circ} 32^{\prime} \mathrm{S}$ '. Further work is needed to better characterise the text impressions but, regardless, it seems possible that one or more of the missing pages contained the statements reported to Curzon. The most likely candidate to have removed these pages is Edward Wilson's widow. Oriana Wilson is known to have destroyed some of her husband's correspondence (Fiennes, 2003) and, given her meeting with Lord Curzon, she probably always intended to remove the offending statements.

Scott's diaries provide the primary source of information on the return journey of the Polar Party and were published almost in their entirety shortly after the return of the expedition (R. F. Scott, 1913a). There are several discrepancies compared to the original text, some of which are relevant to the notes made by Curzon. Most are relatively small changes, such as differences in the recorded temperatures. Others, however, are sufficiently substantive to change the meaning of some entries (Fig. 2) (Scott, 1912a, 2008). For instance, a relatively unknown edit is arguably from one of the most widely quoted sections when Scott's team discovered they had been beaten to the Pole by Amundsen and his men. On 17 January 1912, Scott wrote the following [the missing text in the published version has been underlined]:

Great God! this is an awful place... Now for the run home and a desperate struggle to get the news through first. I wonder if we can do it (R. F. Scott, $\overline{1912 \mathrm{a}, 2008}$ ).

The removal of these few words for the published version changes the meaning of the statement, suggesting Scott knew his team's lives were in danger. Instead, Scott is clearly concerned about whether he can communicate the British team's success in reaching the Pole to the world before Amundsen. Arguably more important, however, are subsequent entries which Scott made over supply levels in the depots and whether his orders had been followed (Fig. 2).

Missing supplies does not appear to have been a oneoff issue. A loss of fuel was found to be a result of leaking lids. But the shortfall in anticipated food happened at least twice. The first occurred on the Polar Party's return journey at the Upper Glacier Depot on 7 February 1912 (Fig. 2), when the team found a full day's biscuit allowance missing. Scott described 'First panic, certainly that biscuit-box was short... The shortage is a full day's allowance' (R. F. Scott, 1913a), a concern confirmed by Wilson who wrote frustratingly that 'breakfast ... was given up to a discussion as to the absence of one day's biscuit' (E. Wilson, 1972).

But the missing pemmican mentioned in Curzon's notes appears to have been later, on 24 February, when the party descended the Beardmore Glacier to reach the Southern Barrier Depot at $82^{\circ} 47^{\prime}$ S (Fig. 2). Neither Wilson nor Scott directly commented at the time on the shortage of food; the recent death of P.O. Evans and the loss of leaking fuel were their immediate concerns. Thanks to Bowers' meticulous planning (Bowers, 2012), Scott and his team expected to find one weeks rations for five men, equivalent to 35 days of food for a single person. Now with only four men remaining and enough food left over from the Lower Glacier Depot to feed the team for one day, they should have had enough food for a total of nearly ten days. At the Southern Barrier Depot, Scott wrote almost reassuringly:

Found store in order except shortage oil - shall have to be very saving with fuel - otherwise have ten full days' provision from tonight and shall have less than 70 miles to go (R. F. Scott, 1913a).

But just three days later, Scott had realised all was not well.

We must open out on food soon... We talk of little but food, except after meals... We are naturally always discussing possibility of meeting dogs, where and when, etc. It is a critical position ... 31 miles to depot, 3 days' fuel at a pinch and 6 days food. Things begin to look a little different; we can open out a little food from tomorrow night... (R. F. Scott, 1913a). 
Even with the loss of P.O. Evans, they were short of a day's full rations compared to the more bullish entry on the 24 February, lending further weight to Curzon's notes. It suggests that one or more individuals did indeed take more than their fair share of food from the Southern Barrier Depot.

After this realisation, Scott frequently remarked upon the shortage in supplies. After reaching the Mid-Barrier Depot on 4 March, Scott became increasingly disillusioned over the team's efforts (underlined text not published in the 1913 edition of Scott's diaries): 'We can expect little from man now except the possibility of extra food at the next depot. A poor one', and in the approach to Mount Hooper on 7 March, he wrote hopingly, 'If we only find the correct proportion of food there' (R. F. Scott, 1912a, 2008). By 10 March, Scott noted despairing: 'Shortage on our allowance all round. I don't know that anyone is to blame but generosity and thoughtfulness have not been abundant. The dogs which would have been our salvation have evidently failed. Meares had a bad trip I suppose. It is a miserable jumble' (R. F. Scott, 1912a, 2008).

The opening part of this statement supports Curzon's notes of his meeting with Kathleen Scott (Curzon, 1913c).

Remarkably, in spite of Scott's comments over a 'shortage on our allowance all round' at the Mount Hooper Depot, Lashly's supposed entry as published in The worst journey in the world reported:

We have taken out our food and left nearly all the pemmican [Mt Hooper depot] as we don't require it on account of none of us caring for it, therefore we are leaving it behind for the others. They may require it. We have left our note and wished them every success on their way, but we have decided it is best not to say anything about Mr Evans being ill or suffering from scurvy (Cherry-Garrard, 1922).

The text is strangely prescient of Scott and his men's predicament, but in Lashly's original diary there is no mention of leaving extra food, let alone pemmican, something that would have greatly helped the returning Polar Party. Furtnermore, in Lashly's original diary, Evans was only explicitly recognised as suffering from scurvy on 10 February, north of One Ton Depot (Fig. 2).

The evidence points towards a drastic revision of the sequence of events to cover up the absence of pemmican from one or more depots. Evans was known to be subsisting almost entirely on pemmican and had, during previous depot laying in the autumn of 1911, caused anger amongst the team when he had procured extra supplies something Wright had been furious about:

I believe this [pemmican] was borrowed from the other tent. Evans' later attempt to borrow more from Birdie Bowers annoyed me to such an extent that I spoke to Bowers or someone else of his party urging them to refuse to do so (Bull \& Wright, 1993).

It is quite possible Crean and Lashly may not have even been aware of the removal of supplies; both were intensely loyal to Scott and would almost certainly have opposed such a move. Regardless, it now seems likely that Evans actually fell down with scurvy considerably further north than Curzon understood. And the original text strongly suggests Evans took the additional pemmican and other supplies when he had not yet succumbed to scurvy, possibly because of his anger at having been sent back early and forced to drag his sledge with just two other men, rather than the expected three. By changing the narrative so that Evans fell down with scurvy before the Southern Barrier Depot, there was at least some justification for the removal of extra food.

\section{Failed orders}

The shortage of food at the depots was not the only challenge that Scott and his men faced on their return. The fatal circumstance that led to the deaths of the Polar Party appears to have been exacerbated by the failure of Evans to act on orders given to him on the Plateau. The orders in question relate to the use of the dog sledge teams. Although a modified version of Scott's orders were reported by Evans (1921), the original orders are detailed in Edward Wilson's sketchbooks (E. Wilson, 1912b). Scott had originally intended that if all went well the dog teams would return from $82^{\circ} 30^{\prime} \mathrm{S}$ and be back at Hut Point by the 10 December so that by early January they could make a second journey south to deliver five units of XS rations, fuel and biscuits to One Ton Depot plus 'as much dog food as convenient' (E. Wilson, 1912b). The dog teams were then to set out from Cape Evans and:

Start 3rd journey south about 1st week of February. To help the most advanced Southern party to catch the ship. Try and meet this party about March 1st in lat. $82^{\circ}$ or $82^{\circ} 30^{\prime}$. If then in a position to mark time for 5 or 6 days, or advance a few short marches on food brought or dead ponies you should be able to effect object. Carry with you beyond One Ton Camp 1 XS ration including biscuit and 1 gallon paraffin \& don't wait beyond time you can safely return on back depots. Your third journey is important. Your second vital. At all hazards 3 XS ration units must be got to One Ton Camp by the date named - and if the dogs can't do this it must be manhauled. (E. Wilson, 1912b).

But during their outward journey, the slow crossing of the Ross Ice Shelf exacerbated by the failure of the motorised sledges, necessitated the use of the dogs down to $83^{\circ} 35^{\prime} \mathrm{S}$, resulting in the latter's late return to Hut Point on 4 January. Although this was accommodated in the original orders, it meant the dogs could no longer undertake the delivery of the five XS rations with dog food on the second journey to One Ton Depot by the date set by Scott. As a result, the 'vital' three units of XS rations were manhauled south along with the fuel and biscuits as ordered. Previous work has questioned why the dog food was not delivered at the same time (May, 2013) but the substantial weight (approximately $330 \mathrm{~kg}$ for 22 days supplies for $22 \mathrm{dogs}$; E. Wilson, 1912b) was too much to be manhauled with the other supplies (May and Airriess, 2014). With Evans 
to be sent back to New Zealand, Atkinson became de facto leader of the expedition on the ice and as he described in the published version of Scott's diaries, the orders were modified to accommodate the expedition's experiences earlier in the season:

[T]wo dog teams [were] to proceed as far south as possible, taking into consideration the times of the return parties, and in order to hasten the return of the final party. The dog teams were in no manner a relief expedition and were simply meant to bring the last party home more speedily... Strict injunctions had been given by Captain Scott that the dogs should not be risked in any way (R. F. Scott, 1913a).

Minimising the risk to the dogs for future expeditionary work was keenly on Scott's mind. Norwegian BAE ski expert Tryggve Gran described in his book Kampen om Sydpolen that Scott had told Meares the dogs were not to be risked climbing the Beardmore Glacier and that the '[d]ogs should meet me. Time and place for this I shall notify through the returning Support Party' (Gran, 1961). After ascending the Beardmore Glacier and before sending Atkinson and his team back, Scott repeated that the dogs were not to be risked and possibly because of the later than hoped for return of the dogs across the Ross Ice Shelf (and potentially limited reprovisioning of One Ton Depot), that the third dog team journey should only 'come as far as you can' (Cherry-Garrard, 1922). But in the final approach to the Pole, Scott's increasing concern over Amundsen's progress and the need to make public the news of their achievement (regardless of who reached the Pole first), apparently reverted to the original orders but with one important modification: instead of travelling as far as $82^{\circ} 30^{\prime} \mathrm{S}$, the British leader is reported to have given a verbal order to Evans that the dogs should travel to the southern end of the Ross Ice Shelf and meet the returning Polar Party as soon as they were off the Antarctic Plateau (Huntford, 2009). Whether Evans received such an order has caused considerable controversy (CherryGarrard, 1922; Evans, 1921; Huntford, 2009; Wheeler, 2002). Some have claimed the order was never given to Evans and that Scott's instructions to Atkinson were disobeyed (May, 2013).

Whilst no orders were apparently written by Scott for the Last Supporting Party, it does seem they were issued on the journey. By the time the two final parties had reached two-and-a-half degrees north of the Pole, Scott had settled on his plans for the dogs on their third journey. Meeting privately with Evans he sent his second-in-command back and ordered the dogs should return across the Ross Ice Shelf to meet the returning party between $82^{\circ}$ and $83^{\circ} \mathrm{S}$ (Gran, 1961). On 29 February 1912, Gran saw Evans on the Terra Nova shortly before the vessel was to return to New Zealand. Gran was sufficiently concerned by what he had learnt to request a relief party be sent to the bottom of the Beardmore Glacier to support Scott's return, a request Evans refused (Hattersley-Smith \& McGhie, 1984). Although sick, Evans was sufficiently lucid to try to convince Gran to return with him to New Zealand that season, a proposal the Norwegian turned down. From Gran's writing and interviews it remains unclear whether he learnt of the revised orders immediately after the rescue of the British lieutenant or on the latter's return on the Terra Nova in 1913 (R. Huntford, personal communication). Shortly after Evans' death, Gran wrote a letter to The Times confirming the order was given: 'Scott reached the South Pole on January 18 and got down the Beardmore Glacier a month later in spite of having been immensely hampered and delayed by a man completely gone to bits. Had Scott, as planned, been met by a dog party at the foot of the Beardmore, Wilson, Oates, Bowers and himself would have got through in a relatively fine condition' (The Times, 15 January 1958, London: 9).

Evans himself later declared he expected the dogs to meet the returning Polar Party when he wrote in a tribute to Oates that 'the last farewell was most touching, Oates being far more affected than any other of the Southern Party... He asked me to send him out tobacco and sweets by the dog teams' (Evans, 1913, The Strand Magazine). But the order was not acted on. Atkinson remained convinced the orders as he understood them had not been rescinded. With Evans needing urgent medical treatment, Atkinson delayed his planned journey south with the dogs (Atkinson, 1912). Because Meares failed to complete the supply of One Ton Depot (May and Airriess, 2014), Atkinson appears to have settled on heading as far south as One Ton Depot to complete the 'vital' second journey and deliver the outstanding two XS ration units; E. Wilson, 1912b). As a result, Atkinson sent Cherry-Garrard sledging south with Russian dog-driver Demetri Gerof and the dogs on 26 February with 24 days of supplies, 21 days of dog food and the two XS rations for One Ton Depot (Cherry-Garrard, 1922) (Fig. 2). There were no orders to replenish depots further south.

There is supporting evidence, however, to suggest that Scott had indeed wanted the dog teams to travel across the Ross Ice Shelf. When news of Scott's death reached the world on 12 February 1913, a devastated Sir Clements Markham wrote to Lord Curzon:

I have just received telegrams with appalling news that Captain Scott and his South Pole party have perished... All the arrangements for depots and supporting sledges were excellent, as Scott's arrangements always were. Mr Cherry-Garrard (a young volunteer who gave $£ 1000$ to the expedition) was to meet the South Pole party, with two teams of dogs, at the foot of the [Beardmore] glacier. As the date, Jan 18, of reaching the Pole was known, the journals must have been recovered. So I think that Cherry-Garrard, when the party never arrived, must have gone up in search (Markham, 1913).

The first newspaper reports do indeed mention CherryGarrard but that he just reached One Ton Camp and returned exhausted with the dogs (The Daily Mail, 11 February 1913, London: 5). The fact that Markham does not refer to this and instead describes Cherry-Garrard 
heading to the bottom of the Beardmore Glacier, which is not mentioned in any of the reports, implies he had a source independent of the public account. The implication is Scott's order to use the dogs to pick him up from the far end of the Ross Ice Shelf was known back in London. The source of this information must have known CherryGarrard and Demetri had set out, but had misunderstood their objective and left McMurdo Sound before their return from One Ton Depot. The most obvious person is the expedition's second-in-command, Evans, who left on the Terra Nova on 4 March 1912, a week after the dog team departed. Evans knew Cherry-Garrard had headed south but had not passed on the order (or at least confirmed this was being acted on) to proceed to the bottom of the glacier or at least as far as he could. As a result there was not the sense of urgency the situation demanded. Scott himself had originally anticipated poor conditions into his planning and indicated he may be delayed until the end of March. Cherry-Garrard and Demetri therefore returned from their journey to One Ton Depot on 16 March 1912, seemingly without concern they had not met the Polar Party.

The implication is that Evans knew Scott wanted the dogs to meet the Polar Party shortly after they had descended the Antarctic Plateau. And yet, as second-incommand, he did not confirm this was being acted on when he reached Cape Evans. Sick or not, he was articulate enough to seek Gran's return with him to New Zealand. The most charitable view on Evans' actions (or lack of them) was that he was ineffectual.

Back in London, Lord Curzon appears to have thought Cherry-Garrard's journey to One Ton Depot was indeed a rescue effort, something the first reports described as a relief mission. In The Daily Mail,

Commander Evans declares that it was humanly impossible for the base party to save Scott and his comrades... The dog-driver Demetri, who with Mr. Cherry-Garrard made the first relief journey towards the south, wanted to make a solitary dash further south from One-Ton Camp, which they left on March 10, but did not persist (The Daily Mail, 15 February 1913, London: 5).

Cherry-Garrard was incensed, writing to Atkinson on 3 April 1913:

I wish to ask that on the earliest really public occasion which arises, whether in writing or speaking, enough should be said or written concerning the purpose and conduct of the Dog Journey. Feb. March 1912 to stop what is being written and said concerning my conduct. I quote an instance from the 'Daily Mail' Overseas Edition... I say it is the duty of the Expedition to tell enough of the truth to make such statements impossible. I want neither praise nor blame, apart from the truth... I think the main cause of difficulty is that is generally supposed that we returned from One Ton with the knowledge that the Southern Party was in trouble (I believe many think we were sent south because they were overdue). Of course this was not so: the temperatures were low from (from memory) about March 4. But when we returned on March 10 there was no reason to suppose the Polar Party was not close to One Ton with plenty of food: in other words there was no reason to kill dogs and push on. We were not to risk the dogs. We came back thinking we had started out too early (Cherry-Garrard, 1913b). As part of his planned enquiry, Curzon wanted to know why the expedition had failed to undertake a rescue, a question most expedition members were at a loss to understand. On 21 April 1913, Atkinson wrote to Kathleen Scott:

I had a very long cross-examination from Lord Curzon today and I shall not be at all sorry to get away for a short holiday. There seems to be some idea that Cherry might have done more. I can assure you no other officer under the circumstances would have done more than Cherry. It is so very difficult to explain to people (Atkinson, 1913).

Although some have proposed Atkinson changed his orders, possibly due to a lack of command experience (May, 2013), there is nothing in the diaries and letters from the time or later to suggest any of the men involved considered this a relief expedition or cause for concern (Cherry-Garrard, 1913a; R. F. Scott, 1913a). If the order for the dogs to cross the Ross Ice Shelf had been clearly passed on, there would have been some attempt to travel beyond One Ton Depot (albeit restricted because of the limited amount of dog food), but this was not considered a priority at the time (Cherry-Garrard, 1922). Indeed, Evans appears to have actively downplayed any concern, refusing Gran's appeal for a relief party to travel to the base of the Beardmore Glacier (Hattersley-Smith \& McGhie, 1984). Tellingly, after Cherry-Garrard and Gerof's return and subsequent collapse, a later effort was made to meet the Polar Party on 26 March by Atkinson and Keohane who manhauled supplies only as far as Corner Camp (Scott, 1913a) (Fig. 1). There was no attempt to proceed further south, something that might have been anticipated if an order to proceed with dogs to the bottom of the Beardmore Glacier had been received.

Cherry-Garrard continued to be troubled that his journey to One Ton Depot was being portrayed as a failed rescue attempt. Writing in January 1914, he described an interview at Lincoln's Inn Fields with the expedition's solicitor, Arthur Ferrar, who was also Cherry-Garrard's own legal advisor. The response was clear. 'They would not listen,' Ferrar insisted when Cherry-Garrard said he wanted to go before the Antarctic Committee handling the expedition in Britain. 'They will say you are overstrained. You see, there must be no scandal.' Cherry-Garrard was worried. 'The Committee (Curzon),' Cherry-Garrard noted in the margin of his journal, 'meant to hush up everything. I was to be sacrificed' (Cherry-Garrard, 1913c; Wheeler, 2002).

Cherry-Garrard remained convinced Evans came out from the expedition far too positively, ruminating in a letter to Atkinson on 20 April 1919 that: 
Teddy Evans is probably suffering from too many medals. A friend tells me the greatest mistake in this Expedition was that God killed the wrong Evans. He comes out of my book far better than I desire or he deserves. The only criticism I can remember is that his getting scurvy was not the fault of the medical side of the Expedition. There will however be an unprinted reference to the Antarctic as a white wall upon which some people have a passion for writing their names. If the cap fits let him put it on (Cherry-Garrard, 1919; something that did not make the final published version of The worst journey in the world).

For Scott and his team, reduced supplies and a failure to follow orders fatally exposed the Polar Party to the extreme conditions they met on the return journey. During their final push across the Ross Ice Shelf, Scott was anticipating his orders had been acted on and the surviving men would soon meet the dog teams. On 27 February 1912, Scott and his men had reached $82^{\circ} \mathrm{S}$ and remarked: We are naturally always discussing possibility of meeting dogs, where and when, \&c. It is a critical position (R. F. Scott, 1913a).

By 10 March, Scott realised the dogs were not coming (Fig. 2):

The dogs which would have been our salvation have evidently failed (R. F. Scott, 1913a).

Two weeks later, Scott was trapped by a blizzard in a tent with his two remaining team members, Wilson and Bowers. Writing from his deathbed, Scott warned Joseph Kinsey (underlined text was not reproduced in the published version of the diaries):

Four days of blizzard just as we were getting to the last depôt. [ 'Now 9' written along the side of the page 'with 'Now' twice underlined] My thoughts have been with you often. You have been a brick - You will pull the expedition together I'm sure. Teddy Evans is not to be trusted over much though he means well (Scott, 1912b).

It was arguably a generous statement.

\section{Conclusions}

Taking more than your allocated supplies strikes at the heart of expeditionary work. Scientific work in extreme environments is by its nature a hazardous occupation, no more so than at the turn of the twentieth century when communications and logistical support were relatively primitive compared to today. If you cannot trust team members in a dangerous environment, the safety of all are threatened. Sadly, the leadership on the BAE appears to have been fundamentally undermined by some highly questionable actions by second-in-command Lieutenant Edward 'Teddy' Evans. Evans' insistence that Skelton not participate on the expedition, significantly weakened the ability of the motorised sledges to transport supplies across the Ross Ice Shelf, while his failure to effectively communicate Scott's orders for the dog sledge teams to expedite the Polar Party's return after they had des- cended the Beardmore Glacier, resulted in fatal delays. Arguably more importantly, recently discovered notes from meetings between Lord Curzon and the widows of Captain Scott and his confidant Edward Wilson, point to Evans' unauthorised removal of food from depots that were meant for Scott and the Polar Party. It appears that Curzon and others associated with the expedition accepted that this may have been necessary because Evans had been stricken by scurvy when the food was removed. However, further analysis of key texts from the time indicates that this was not the case and that the timeline of Evans' sickness was deliberately changed to align with the removal of the supplies. It is hoped future analysis of original (unpublished) texts will cast further light on Evans' actions and why he was not questioned further on his return to Britain.

\section{Acknowledgements}

Many thanks to Naomi Boneham for all her help at the Scott Polar Research Institute (Cambridge, UK), including checking key text for me from William Lashly's sledging diary and providing contacts for permissions to quote, and Roland Huntford for confirming the source of Tryggve Gran's description of Scott's verbal orders. I would also like to thank the staff of the British Library, particularly William Frame who arranged for the analysis of Edward Wilson's sledging diary, Louisa Young for permission to quote from Kathleen Scott's diaries (Kennet Papers), Hugh Turner for permission to quote from Cherry-Garrard's diaries and correspondence, Sarah Airriess for her enthusiasm, insights and comments on a previous draft, the British Library for quoting from Lord Curzon's notes and correspondence, Stephanie Volkens at the State Library of New South Wales for advising on quoting from their archived material, Linda McGregor at the Alexander Turnbull Library for permission to quote from Captain Robert Falcon Scott's letter to Joseph Kinsey (1911) Julian Evans for permission to quote from Lt Evans' letter to Captain Irving and for confirming the status of E.R.G.R. Evans' sledging diary, the Skelton family estate for permission to quote from Reginald Skelton's correspondence in 1912: the year the world discovered Antarctica, and George and Valerie Skinner for searching for any correspondence between William Lashly and Evans. Christopher Fogwill and Zoë Thomas kindly commented on early drafts of this paper. Many thanks for the insightful reviews by two anonymous referees and editor Trevor McIntyre.

\section{Conflict of interest}

None.

\section{References}

Atkinson, E. (1912). Letter to Charles Wright, 22 February 1912 (MS 1178/1;D). Cambridge: Scott Polar Research Institute.

Atkinson, E. (1913). Letter to Kathleen Scott, 21 April 1913 (MS 1453/46/1-12;D). Cambridge: Scott Polar Research Institute. 
Atkinson, E. (1919). Letter to Apsley Cherry-Garrard, 5 December 1919 (MS 873/2/1;WJ). Cambridge: Scott Polar Research Institute.

Back, J. D. (1992). The quiet land: the diaries of Frank Debenham. Bluntisham: Bluntisham Books/Erskine Press.

Baigent, E. (2010). 'Deeds not words'? Life writing and early twentieth-century British polar exploration. In: Naylor, S. \& Ryan, J. R. (Eds.), New spaces of exploration: geographies of discovery in the twentieth century (pp. 23-51). London: I.B. Tauris.

Beaumont, L. (1913a). Letter to Kathleen Scott, 15 March 1913 (MS 2;D). Cambridge: Scott Polar Research Institute.

Beaumont, L. (1913b). Letter to Lord Curzon, 17 April 1913 (Mss.Eur.F112/51). London: British Library.

Beaumont, L. (1913c). Letter to Kathleen Scott, 18 April 1913 (MS 2;D). Cambridge: Scott Polar Research Institute

Beaumont, L. (1913d). Letter to Lord Curzon, 19 April 1913 (Mss.Eur.F112/51). London: British Library.

Beaumont, L. (1913e). Letter to Lord Curzon, 24 April 1913 (Mss.Eur.F112/51). London: British Library.

Bomann-Larsen, T. (2006). Roald Amundsen. Stroud: Sutton Publishing.

Bowers, H. (2012). The South Pole journals. Cambridge: Scott Polar Research Institute.

Bull, C. \& Wright, P. F. (1993). Silas: the Antarctic diaries and memoir of Charles S. Wright. Columbus, $\mathrm{OH}$ : Ohio State University Press.

Cherry-Garrard, A. (1913a). Diary, 16 January to 15 March 1913 (MS 559/11;BJ). Cambridge: Scott Polar Research Institute.

Cherry-Garrard, A. (1913b). Letter to Edward Atkinson, 3 April 1913 (MS 559/42;D). Cambridge: Scott Polar Research Institute.

Cherry-Garrard, A. (1913c). Annotated Diary (Volume 4), 12 October 1912 to 9 March 1913 (MS 554/19/4). Cambridge: Scott Polar Research Institute.

Cherry-Garrard, A. (1916). Letter to William Lashly, 5 May 1916 (MS 873/2/12;WJ). Cambridge: Scott Polar Research Institute.

Cherry-Garrard, A. (1919). Letter to Edward Atkinson, 20 April 1919 (MS 873/2/1;WJ). Cambridge: Scott Polar Research Institute.

Cherry-Garrard, A. (1922). The worst journey in the world (republished 2003). London: Pimlico.

Crane, D. (2006). Scott of the Antarctic. London: Harper Perennial.

Curzon, G. N. (1913a). Letter to Kathleen Scott, 15 April 1913 (MS 4;D). Cambridge: Scott Polar Research Institute.

Curzon, G. N. (1913b). Letter to Kathleen Scott, 17 April 1913 (MS 841/1/1-2;D). Cambridge: Scott Polar Research Institute.

Curzon, G. N. (1913c). Notes, 16 April 1913 (BL MSS EUR/F112/51). London: British Library.

Darwin, L. (1913). Letter to Lord Curzon, 18 April 1913 (Mss.Eur.F112/51). London: British Library.

Ellis, A. R. (1969). Under Scott's command: Lashly's Antarctic diaries. New York, NY: Taplinger Publishing.

Evans, E. R. G. R. (1912). Letter to Captain J. P. Irven, 5 July 1912 (MLDOC 1468). Sydney: Mitchell Library. Retrieved from: http://archival.sl.nsw.gov.au/Details/archive/ 110359048.

Evans, E. R. G. R. (1913). The British Antarctic Expedition, 1910-13. The Geographical Journal, 42, 11-28.

Evans, E. R. G. R. (1921). South with Scott. London: Collins Clear-Type Press.

Evans, E. R. G. R. (1943). British polar explorers. London: William Collins.
Fiennes, R. (2003). Captain Scott. London: Hodder \& Stoughton. Goldie, G. T. (1913). Letter to Lord Curzon, 18 April 1913 (Mss.Eur.F112/51). London: British Library.

Gran, T. (1961). Kampen om Sydpolen. Oslo: Ernst G. Mortensen.

Hattersley-Smith, G. \& McGhie, E. J. (1984). The Norwegian with Scott: Tyggve Gran's Antarctic diary 1910-1913. London: Her Majesty's Stationary Office.

Huntford, R. (2009). Scott and Amundsen: their race to the South Pole. London: Abacus.

Lashly, W. (1912). Diary, 24 September 1911 to 19 February 1912. MS 890/2;BJ. Cambridge: Scott Polar Research Institute.

Lashly, W. (1916). Letter to Apsley Cherry-Garrard, 11 July 1916 (MS 873/2/12;WJ). Cambridge: Scott Polar Research Institute.

Markham, C. (1913). Letter to Lord Curzon, 12 February 1913 (BL MSS EUR/F112/51). London: British Library.

May, K. \& Airriess, S. (2014). Could Captain Scott have been saved? Cecil Meares and the 'second journey' that failed. Polar Record, 51, 260-273.

May, K. (2013). Could Captain Scott have been saved? Revisiting Scott's last expedition. Polar Record, 49, 72-90.

Ponting, H. G. (Writer). (1924). The great white silence. London: British Film Institute (2011).

Scott, K. (1913). Diary (Kennet D/5). Cambridge: Cambridge University Library.

Scott, R. F. (1911). Letter to Joseph Kinsey, 28 October 1911 (MS-Copy-Micro-0528-1). Wellington: Alexander Turnbull Library.

Scott, R. F. (1912a). Diary (Add. MS 51035). London: British Library.

Scott, R. F. (1912b). Letter to Joseph Kinsey, 24 March 1912 (MLMSS 5599). Sydney: Mitchell Library.

Scott, R. F. (1913a). Scott's last expedition. London: Smith, Elder $\&$ Co.

Scott, R. F. (1913b). To the South Pole. Captain Scott's own story told from his journals. Part III. Edited by Evans, E. The Strand Magazine, 46 (September), 245-264.

Scott, R. F. (2008). Journals: Captain Scott's last expedition. Oxford: Oxford World's Classics.

Simpson, G. C. (1923a). The meteorology of Scott's last journey. Nature, 111, 758-759.

Simpson, G. C. (1923b). Meteorology Vol. III: tables (British Antarctic Expedition 1910-1913). London: Harrison and Sons.

Skelton, R. (1907). Letter regarding motorised sledge design, 11 June 1907 (MS 342/10/1/5). Cambridge: Scott Polar Research Institute.

Skelton, R. (1910a). Letter to R.G.R. Evans, 22 March 1910 (MS 342/13;D). Cambridge: Scott Polar Research Institute.

Skelton, R. (1910b). Letter to R.F. Scott, 31 March 1910 (MS 342/14/5). Cambridge: Scott Polar Research Institute.

Skelton, R. (1911). Letter to R.F. Scott, 8 October 1911 (MS 342/14/9). Cambridge: Scott Polar Research Institute.

Solomon, S. (2001). The coldest March: Scott's fatal Antarctic expedition. New Haven, CT: Yale University Press.

Solomon, S. \& Stearns, C. R. (1999). On the role of the weather in the deaths of R. F. Scott and his companions. Proceedings of the National Academy of Sciences, 96, 13012-13016.

Turney, C. (2012). 1912: the year the world discovered Antarctica. Melbourne: Text Publishing.

Turney, C. (2014). Captain Scott's secret. History Today, 64, 4041.

Wheeler, S. (2002). Cherry: a life of Apsley Cherry-Garrard. London: Vintage. 
Wilson, E. (1912a). Diary (Add MS 45459). London: British Library.

Wilson, E. (1912b). Sledging sketchbooks (MS797/1-2 BJ). Cambridge: Scott Polar Research Institute.
Wilson, E. (1972). Diary of the Terra Nova expedition to the Antarctic 1910-1912. New York, NY: Humanities Press.

Wilson, O. (1913). Letter to Lord Curzon, 20 April 1913 (Mss.Eur.F112/51). London: British Library. 